\title{
PERANCANGAN INTEGRASI SISTEM INFORMASI AKADEMIK DENGAN E-LEARNING \\ (Studi Kasus : Program Studi XYZ)
}

\author{
Brav Deva Bernadhi ${ }^{*}$, Singgih Saptadi \\ Teknik Industri, Fakultas Teknologi Industri, Universitas Islam Sultan Agung \\ Semarang, Indonesia
}

(Received: August 9, 2016 / Accepted: December 21, 2016)

\begin{abstract}
ABSTRAK
Pertumbuhan akses informasi pada saat sekarang ini berjalan secara pesat. Masyarakat atau user untuk mendapatkan data atau informasi yang akurat, aktual, serta cepat dan mudah sekarang bukanlah hal sulit. Perkembangan internet pada saat ini semakin pesat dan tidak dapat dipisahkan dari dunia pendidikan. Terdapatnya sistem informasi dan internet yang terus berkembang, maka diciptakan suatu cara penyampaian pendidikan secara elektronik dengan bantuan internet. Sistem informasi yang dimaksud pada saat sekarang lebih dikenal dengan istilah elektronik learning (e-learning). E-learning adalah suatu sistem informasi yang membantu pembelajaran manual menjadi pembelajaran secara elektronik. Pada dunia pendidikan untuk membantu dosen dan mahasiswa untuk memanajemen mata kuliah, saat sekarang ini terdapat Sistem Informasi Akademik yang lebih disingkat dengan SIA. SIA adalah suatu sistem informasi yang mengelola dan mengolah semua data-data akademik yang berada di bidang akademik. KRS online yang berada di SIA berhubungan erat dengan mata kuliah yang akan terisi pada e-learning. Dari pandangan kebutuhan tersebut, ada baiknya kedua sistem informasi tersebut digabungkan sehingga dengan user mengisi SIA, maka sistem e-learning yang berhubungan dengan mata kuliah yang diikuti akan terupdate dengan sendirinya dan perlu didesain sedemikian rupa agar kedua sistem informasi tersebut dapat berjalan dengan baik dan dapat digunakan oleh para user. Pendekatan ergonomis yang diperlukan untuk sistem tersebut adalah Human Computer Interaction (HCI) sehingga sistem yang dikembangkan akan nyaman, mudah dan aman digunakan oleh user atau dengan kata lain adalah user friendly. Jurnal ini disusun dengan tujuan untuk mengembangkan suatu sistem integrasi SIA dengan elearning sehingga dapat membantu dan mempermudah aktifitas pembelajaran di Perguruan Tinggi.
\end{abstract}

Kata Kunci: ICT, HCI, SIA, e-learning, ergonomi IT

\begin{abstract}
Growth of access to information at the present time is running fast. Public or the user to obtain data or information that is accurate, current, and a quick and easy right now is not difficult. The development of the Internet in today's increasingly rapidly and can not be separated from the world of education. Presence information systems and the Internet continues to grow, then created a way of delivering education electronically with the help of internet. The information system is at present better known as electronic learning (e-learning). E-learning is an information system that helps instructional manual to electronic learning. In the world of education to enable faculty and students to manage course, nowadays there are more Academic Information System shortened by SIA. SIA is an information system that manages and processes all the data of academic residing in the academic field. KRS SIA online that are closely related to the subjects that will be filled in e-learning. From the view of these needs, it helps both information systems are combined so that the user fills in SIA, the e-learning systems relating to subjects who follow will update itself and needs to be designed so that both the information system can run well and can used by the user. Ergonomic approach is needed for these systems is the Human Computer Interaction (HCI) so that the developed system will be convenient, easy and safe to use by the user, or in
\end{abstract}

\footnotetext{
${ }^{*}$ Penulis Korespondensi. email: deva@unissula.ac.id
} 
other words is user friendly. These journals are intended to develop a system AIS integration with elearning in order to assist and facilitate the activities of learning in Higher Education.

Keywords: ICT, HCI, SIA, E-Learning, IT ergonomics

\section{Pendahuluan}

Akses informasi pada saat sekarang ini berkembang secara pesat. Masyarakat atau user untuk mendapatkan data atau informasi yang akurat, aktual, serta cepat dan mudah sekarang bukanlah hal sulit. Hal ini terutama merupakan dampak dari kemajuan teknologi informasi dan komputer yang kini kian berkembang (Supriyanto, 2005).

Perkembangan internet pada saat ini semakin pesat dan tidak dapat dipisahkan dari dunia pendidikan. Internet berasal dari kependekan Interconnection Networking yang berarti seluruh komputer yang terhubung pada jaringan yang menggunakan sistem Transmission Control Protocol/Internet Protocol (TCP/IP) untuk berbagi informasi secara bersama (Supriyanto, 2005). Internet adalah media yang nyaman dan ideal untuk penyebaran informasi ilmu pengetahuan dan teknologi (iptek) serta konten pembelajaran (Suryadi, 1997). Seorang mahasiswa dapat mengakses materi pembelajaran dan mempelajarinya di manapun dan kapanpun. Sistem pembelajaran melalui internet dapat dilakukan dosen pengampu dengan cara menggunakan blog atau e-mail. Jika mahasiswa yang bersangkutan mengalami kesulitan, mahasiswa tersebut dapat segera menghubungi dosen yang bersangkutan menggunakan e-mail dosen tersebut. Pendapat (Monohan, 2006) tentang sistem tersebut yaitu sebuah repository pengetahuan dan informasi yang cukup memberikan materi khusus dalam format HTML bagi peserta didik untuk mengakses, membaca dan belajar.

Perkembangan dunia pendidikan juga sejalan dengan dunia sistem informasi. Pada umumnya proses belajar-mengajar di Program Studi XYZ disampaikan secara konvensional, maksudnya antara penerima dan penyampai suatu pendidikan harus bertemu secara langsung. Dalam perkembangan jaman, sistem informasi dan internet maka diciptakan suatu cara penyampaian pendidikan secara elektronik dan dengan bantuan internet. Sistem informasi yang dimaksud pada saat sekarang lebih dikenal dengan istilah elektronik learning (e-learning). E-learning adalah suatu sistem informasi yang membantu pembelajaran konvensional menjadi pembelajaran secara elektronik (Rosenberg, 2001). Dapat pula dikatakan e-learning adalah sebuah solusi penyampaian pembelajaran dan ilmu pengetahuan dengan menggunakan teknologi internet (Rosenberg, 2001). Terdapat beberapa komponen yang membentuk sebuah sistem elearning yang dikembangkan (Wahono, 2008), yaitu :

1) Infrastruktur e-Learning : dapat berupa personal computer (PC), jaringan komputer, internet dan perlengkapan multimedia. Sinkronisasi elearning itu sendiri yaitu guru dan siswa dalam kelas dan waktu yang sama meskipun secara tempat berbeda.

2) Sistem dan aplikasi e-Learning : sistem perangkat lunak yang memvirtualisasi proses belajar mengajar konvensional. Bagaimana manajemen kelas, pembuatan materi atau konten, forum diskusi, sistem penilaian (rapor), sistem ujian secara online dan segala fitur yang berhubungan dengan manajemen proses belajar mengajar. Sistem perangkat lunak tersebut sering disebut dengan Learning Management System (LMS). LMS banyak yang berupa open source sehingga dapat kita manfaatkan dengan mudah dan murah untuk dibangun di sekolah dan univeritas.

3) Konten e-Learning : konten dan bahan ajar yang ada pada Learning Management System (LMS). Konten dan bahan ajar ini bisa dalam bentuk Multimedia-base content (konten berbentuk multimedia interaktif) atau Text-based content (konten berbentuk teks seperti pada buku pelajaran biasa). Biasa disimpan dalam Learning Management System (LMS), sehingga dapat dijalankan oleh siswa kapanpun dan dimanapun.

Di dunia pendidikan untuk membantu dosen dan mahasiswa dalam memanajemen mata kuliah, saat sekarang ini terdapat Sistem Informasi Akademik yang lebih disingkat dengan SIA. SIA adalah suatu sistem informasi yang mengelola dan mengolah semua data-data akademik yang berada di bidang akademik. SIA yang berada pada perguruan tinggi berisi tentang informasi dosen, mahasiswa yang bersangkutan, dan mata kuliah yang akan diikuti mahasiswa yang bersangkutan dengan cara mengisi Kartu Rencana Studi (KRS) online.

Sistem e-learning dan SIA hampir mempunyai kemiripan karena sama-sama digunakan di dunia pendidikan atau akademik dan berurusan dengan dosen dan mahasiswa. KRS online yang berada di SIA berhubungan erat dengan mata kuliah yang akan terisi pada e-learning. Dari pandangan kebutuhan itulah, ada baiknya kedua sistem informasi tersebut digabungkan sehingga dengan user mengisi SIA, maka sistem e-learning yang berhubungan dengan mata kuliah yang diikuti akan termutakhirkan dengan sendirinya dan perlu didesain sedemikian rupa agar kedua sistem informasi tersebut dapat berjalan dengan baik dan dapat digunakan oleh para user.

Dari hubungan sistem tersebut terjadilah interaksi manusia dengan komputer (Human Computer Interaction). (Jin, 2001) dalam jurnalnya menjelaskan jika interaksi manusia dengan komputer adalah sebuah sistem antarmuka yang dapat dirancang untuk secara aktif dapat berkolaborasi 
dengan pengguna manusia. Interaksi antara manusia dengan komputer terjadi semisal saat manusia ingin melakukan penyimpanan data yang telah dikerjakan ke dalam harddisk komputer. Pada aplikasi di dalam komputer, terdapat menu save (menyimpan) dan delete (menghapus). Jika sebagai user (pengguna) kita salah melakukan pemilihan tersebut, maka akan terjadi pembuangan jam kerja diakibatkan file kita yang terhapus. Satu aspek dalam HCI adalah kemudahan pengguna dalam menggunakan sistem, dimana salah satunya adalah proses penggunaan dua sistem aplikasi yang berbeda terjadi secara transparan. Ini menuntut integrasi dua sistem aplikasi yang berbeda. Terkait dengan e-learning dan sistem informasi akademik, Program Studi XYZ dihadapkan pada masalah belum terintegrasinya kedua aplikasi tersebut yang sudah diimplementasikan di lingkungan belajar-mengajarnya, sehingga pengguna, dalam hal ini mahasiswa, tidak cukup mudah memanfaatkan keduanya.

\section{Tinjauan Pustaka \\ Ergonomi dan ICT}

Dalam kehidupannya, manusia pasti membutuhkan peralatan pembantu untuk menyelesaikan suatu pekerjaan. Di dunia pendidikan, dosen dan mahasiswa juga memerlukan peralatan pembantu untuk proses pembelajaran. Peralatan pembantu yang digunakan tersebut terkadang memunculkan masalah terhadap penggunanya. Komputer merupakan suatu peralatan yang digunakan manusia untuk menyelesaikan suatu pekerjaan yang berhubungan dengan teknologi informasi. Dari munculnya masalah-masalah terhadap penggunaan komputer, maka terdapat pembahasan tentang ergonomi pada bidang teknologi informasi (IT). Fungsi ergonomi IT tidak hanya berfokus pada hardware (perangkat keras) tetapi juga pada software (perangkat lunak). Perancangan hardware dan software harus terdapat sisi ergonomisnya (Sulianta, 2010).

Berbicara masalah ergonomi dalam perangkat lunak tidak terlepas dari disiplin ilmu lain yang menjadi dasar ergonomi perangkat lunak (Sulianta, 2010), yaitu :

a) Ilmu komputer, sebagai landasan pembuatan teknologi.

b) Psikologi kognitif, mempelajari persepsi manusia, kemampuan manusia dan keterbatasan manusia dalam memecahkan masalah.

c) Ilmu sosial, konsep interaksi

d) Bisnis, proses bisnis dan arus transaksi

e) Desain grafis, perancangan antarmuka

f) Ergonomi, kemampuan indra-indra pemakai terhadap produk teknologi informasi.

Sebuah perangkat lunak (software) yang memenuhi konsep ergonomi, pasti hal tersebut tidak lepas dari Information \& Communication Technology (ICT). Penjelasan dari (Tinio, 2002) menjelaskan bahwa ICT yaitu :
"Beragam alat teknologi dan sumber daya yang digunakan untuk berkomunikasi, dan untuk membuat, menyebarkan, menyimpan dan mengelola informasi."

Penggunaan era digital untuk membantu proses pembelajaran telah banyak diaplikasikan di negaranegara, salah satunya di Eropa. Pembelajaran seperti menggunakan blog, website atau media sosial pembelajaran yang lain telah banyak diaplikasikan. Sehingga dapat dikatakan sebagai "New Millenium Learners" (Redecker, 2009).

Mengaplikasikan teknologi komunikasi dan informasi di dunia pendidikan adalah salah satu tujuan untuk meningkatkan kualitas pendidikan di Indonesia. Penerapan ICT di dunia pendidikan memunculkan sebuah media pembelajaran online yaitu e-learning. Namun demikian, media pembelajaran berbasis ICT dan e-learning masih belum banyak dikembangkan dan dimanfaatkan di Indonesia. Oleh karena itu, perlunya kesadaran masyarakat Indonesia untuk lebih memberikan perhatian pada peningkatan kuantitas dan kualitas media pembelajaran berbasis ICT dan pemanfaatannya di Indonesia.

\section{Human Computer Interaction}

Human Computer Interaction mempelajari bagaimana manusia berinteraksi dengan komputer dan mengkondisikan sebuah sistem komputer mempermudah dan membuat lancar pekerjaan manusia (Sudarmawan dan Ariyus, 2007).

a) Manusia

Manusia dipandang sebagai sistem yang memproses informasi, yang bisa dijelaskan sebagai berikut :

1) Informasi diterima dan ditanggapi dengan proses masukan-keluaran (input-output).

2) Informasi disimpan di dalam ingatan (memory).

3) Informasi diproses dan diaplikasikan dengan berbagai cara.

Proses pemasukan dan pengeluaran yang terjadi pada manusia merupakan suatu vision (pandangan). Proses ini ada dua tahap, yaitu :

1) Pemasukan secara fisik dari stimulus.

2) Pengelolaan dan interpretasi dari stimulus.

Alat fisik yang digunakan untuk mendapatkan visi adalah mata. Proses yang terjadi pada mata untuk mendapatkan visi adalah :

1) Merupakan suatu mekanisme penerimaan cahaya yang ditransformasikan ke dalam energi elektrik.

2) Cahaya memantul dari objek-objek yang dipandang dan citra dari objek tersebut difokuskan secara terbalik pada retina.

3) Retina mengandung rod (organ berbentuk batang) untuk pandangan cahaya lemah dan cone (organ berbentuk kerucut) untuk pandangan berwarna.

4) Sel ganglion (pusat syaraf) berfungsi untuk mendeteksi pola dan pergerakan. 
b) Komputer

Komputer didefinisikan sebagai perangkat elektronik yang dapat dipakai untuk mengolah data dengan perantaraan sebuah program yang mampu memberikan informasi dan hasil dari pengolahan tersebut. Komputer dapat pula diartikan sebagai suatu mesin yang menerima input untuk diproses dan menghasilkan output.

Sistem computer terdiri dari prosesor, memory, I/O. Fungsi dasar yang dibentuk oleh sistem komputer adalah eksekusi program. Program yang akan dieksekusi berisi sejumlah instruksi yang disimpan di dalam memori. CPU melakukan tugas ini dengan cara mengeksekusi program.

Input berhubungan dengan proses perekaman dan pemasukan data ke dalam sistem komputer dan memberi perintah ke komputer. Agar dapat berinteraksi dengan sistem komputer secara efektif, pengguna harus mampu mengkomunikasikan keinginannya dengan cara yang dapat dimengerti sistem komputer.

Salah satu kunci dalam membantu dalam pemilihan piranti input dan memutuskan bagaimana akan digunakan untuk mengendalikan suatu kejadian dalam sistem adalah dengan membantu pengguna untuk menyelesaikan pekerjaannya dengan aman, efektif, efisien, dan jika mungkin menyenangkan. Pemilihan piranti input harus memberi kontribusi positif terhadap penggunaan sistem. Secara umum piranti input yang paling tepat akan memenuhi salah satu faktor berikut:

1) Cocok dengan karakteristik psikologi pengguna, keahlian dan training yang pernah dilakukan. Sebagai contoh, orang yang lebih tua mungkin dibatasi oleh kondisi seperti arthitis sehingga tidak mampu untuk mengetik. Pengguna yang belum berpengalaman mungkin tidak familiar dengan layout keyboard.

2) Sesuai dengan tugas yang akan dilakukan. Misalnya tugas menggambar membutuhkan piranti input yang dapat melakukan gerakan secara kontinyu, Untuk memilih dari suatu daftar pilihan membutuhkan piranti input yang dapat melakukan gerakan secara diskret .

3) Sesuai dengan maksud pekerjaan dan lingkungannya. Sebagai contoh, masukan suara berguna pada situasi dimana tidak ada permukaan untuk meletakkan keyboard, tetapi tidak cocok dengan kondisi berderau. Scanning otomatis akan cocok jika terdapat sejumlah data yang harus dimasukkan.

Dalam praktek tidak ada satu piranti input yang dapat memenuhi semua kebutuhan. Umumnya diperlukan lebih dari satu piranti input agar dapat saling melengkapi, misalnya keyboard dan mouse. Secara umum piranti input harus mudah digunakan dan bentuknya harus ergonomis dan mempunyai sistem umpan balik yang baik.

Jurnal Teknik Industri, Vol. XI, No. 3, September 2016 c) Interaksi

Interaksi membantu manusia, apa yang terjadi antara user dan sistem komputer. Sistem interaksi menerjemahkan antara apa yang diinginkan oleh user terhadap sistem yang ada (Sharp, dkk, 2007). Jika user ingin melakukan pekerjaan tertentu, maka user harus terlebih dahulu tahu program apa yang tepat digunakan untuk menyelesaikan pekerjaan tersebut. Jika pemilihan program untuk pengolahan tidak tepat, maka akan terjadi kesalah-pahaman antara user dengan sistem. Tapi jika user menggunakan program yang tepat, maka user akan dapat menyelesaikan pekerjaan tersebut menggunakan piranti keyboard. Hubungan antara user dan komputer dijembatani oleh antarmuka pengguna (user interface). Proses interaksi antara user dan sistem terdapat kerangka kerja interaksi, yang mana hal tersebut melibatkan 4 komponen. Keempat komponen tersebut adalah user (US), input (I), system (SY) dan output $(\mathrm{O})$.

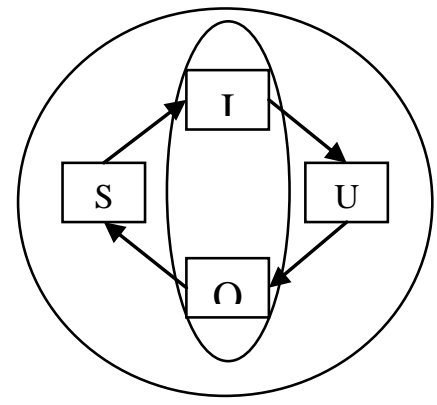

Gambar 1. Kerangka Kerja Interaksi

Sumber : (Sudarmawan dan Ariyus, 2007)

Setiap aplikasi mempunyai ragam dialog yang berbeda. Ragam dialog harus disesuaikan dengan karakteristik tugas atau fungsi aplikasi, dan tentu saja dengan karakter penggunanya. Dalam kenyataannya tidak ada satu ragam yang ekslusif. Kebanyakan sistem menggunakan kombinasi beberapa ragam dialog.

Ragam dialog adalah cara pengorganisasian berbagai teknik dialog interaktif yang memungkinkan terjadinya komunikasi antara manusia dengan komputer. Perbedaan ragam dialog aplikasi yang bekerja pada lingkungan DOS dengan lingkungan Windows. Tujuan perancangan antarmuka dengan berbagai dialog pada dasarnya adalah untuk mendapatkan satu kriteria yang sangat penting dalam pengoperasian sebuah program aplikasi yaitu aspek ramah dengan pengguna (user friendly).

\section{Konsep E-Learning}

Istilah $e$-Learning mengandung pengertian yang sangat luas, sehingga banyak pakar yang menguraikan tentang definisi e-Learning dari berbagai sudut pandang. Salah satu definisi yang cukup dapat diterima banyak pihak misalnya dari (Hartley, 2001) yang menyatakan: 
e-Learning merupakan suatu jenis belajar mengajar yang memungkinkan tersampaikannya bahan ajar ke siswa dengan menggunakan media Internet, Intranet atau media jaringan komputer lain.

Penggunaan $e$-Learning dalam dunia pendidikan memiliki beberapa keuntungan, diantaranya adalah sebagai berikut :

a) Menghemat waktu proses belajar mengajar

b) Mengurangi biaya perjalanan

c) Menghemat biaya pendidikan secara keseluruhan (infrastruktur, peralatan, dan buku-buku)

d) Menjangkau wilayah geografis yang lebih luas dan jauh

e) Melatih user (mahasiswa) lebih mandiri dalam mendapatkan ilmu pengetahuan.

\section{Metodologi Peneltian}

Tahapan penelitian berisi tentang langkahlangkah yang dilakukan peneliti dalam melakukan penelitian mulai dari awal hingga akhir. Tahapan penelitian tersebut dapat terlihat pada gambar di bawah ini.

1) Tahap Penelitian Awal

a) Studi Pendahuluan

Studi pendahuluan dilakukan untuk dapat mengetahui latar belakang permasalahan di dalam objek penelitian yang kemudian permasalahan tersebut berusaha untuk diselesaikan oleh peneliti melalui penelitian yang akan dilakukan ini.

b) Penentuan Tujuan Penelitian

Berdasarkan studi pendahuluan dan perumusan masalah yang ada, maka tahap selanjutnya adalah menetapkan tujuan penelitian. Tujuan penelitian ditetapkan agar penelitian yang dilakukan dapat menjawab dan menyelesaikan rumusan masalah yang dihadapi. Tujuan dari penelitian ini adalah merancang integrasi antara Sistem Informasi Akademik (SIA) dengan e-Learning pada Program Studi XYZ.

2) Tahap Pengolahan

a) Analisis Sistem

Pada tahap penelitian ini dilakukan analisis sistem database yang digunakan pada Sistem Informasi Akademik (SIA) dan e-Learning pada Program Studi XYZ. Tahapan ini perlu dilakukan untuk menyusun alternatif-alternatif desain sistem yang baru. Alternatif-alternatif tersebut nantinya akan dipilih satu alternatif yang terbaik dan akan dilanjutkan menuju desain sistem.

b) Desain Sistem

Setelah terpilih satu alternatif yang terbaik pada tahap analisis sistem, maka selanjutnya dilakukan desain sistem yang baru yang nantinya sistem tersebut akan dikembangkan menjadi sistem aplikasi database yang baru. Sistem tersebut akan dilakukan pengembangan dan penerapan pada tahap selanjutnya. c) Pengembangan Sistem Baru

Pada tahap pengembangan sistem baru ini, sistem aplikasi yang baru akan dikembangkan pada Sistem Informasi Akademik (SIA) dan eLearning pada Program Studi XYZ. Sistem baru ini yang berfungsi untuk mengintegrasikan antara SIA dan e-learning pada Program Studi XYZ sehingga dosen dan mahasiswa akan terbantu dengan keberadaan sistem tersebut.

3) Kesimpulan

Tahap akhir dari penelitian ini adalah berupa kesimpulan terhadap analsis hasil pengolahan dan pengimplementasian sistem baru tersebut. Sistem baru yang merupakan suatu sistem yang membantu mengintegrasikan antara SIA dengan e-learning pada Program Studi XYZ.

\section{Alternatif-Alternatif Desain Sistem Integrasi yang akan digunakan}

Terdapat tiga (3) alternatif desain sistem integrasi yang akan dianalisis dalam penelitian ini. Ketiga alternatif tersebut akan dipilih satu alternatif yang terbaik. Berikut ini akan dijelaskan dan dianalisa alternatif-alternatif tersebut.

1) SIA + e-Learning dalam satu aplikasi baru

SIA + e-Learning dalam satu (1) aplikasi baru maksudnya adalah peneliti merancang dan mengembangkan aplikasi baru yang mempunyai fungsi sama dengan SIA dan e-Learning. Aplikasi baru tersebut juga nantinya akan mempunyai database baru dan aplikasi tersebut telah menjadi sistem integrasi kedua sistem informasi tersebut (SIA dan e-Learning). Gambaran dari alternatif pertama dapat dilihat pada gambar 2 .

Adapun keunggulan dan kendala pada alternatif pertama ini, keunggulan dan kendala tersebut antara lain :

a) Keunggulan :

- Integrasi telah terdapat pada satu sistem yang sama.

- Aplikasi yang baru lebih ringkas karena terdapat pada satu sistem, sehingga user hanya perlu membuka satu sistem yang mempunyai fungsi SIA dan e-Learning.

- Pengelolaan sistem dan database lebih mudah karena hanya terdapat satu sistem dan satu database.

b) Kendala :

- Kebutuhan sosialisasi ulang karena terjadi perubahan pada sistem SIA dan e-Learning.

- Waktu pengembangan aplikasi baru yang lama.

- Dibutuhkan migrasi atau perpindahan dari database lama ke database baru dan hal tersebut membutuhkan waktu yang lama untuk menganalisa seluruh tabel di database lama agar database baru mempunyai fungsi yang sama dengan database lama. 
2) SIA + e-Learning dalam satu proses

SIA + e-Learning dalam satu (1) proses maksudnya adalah peneliti merancang dan mengembangkan aplikasi baru SIA dan eLearning dalam satu (1) proses sistem tapi aplikasi tersebut masih menggunakan database yang lama. Gambaran dari alternatif kedua dapat dilihat pada gambar 3 .

Adapun keunggulan dan kendala pada alternatif kedua ini, keunggulan dan kendala tersebut antara lain :

a) Keunggulan :

- Integrasi telah terdapat pada satu sistem yang sama.

- Aplikasi yang baru lebih ringkas karena terdapat pada satu sistem, sehingga user hanya perlu membuka satu sistem yang mempunyai fungsi SIA dan e-Learning.

b) Kendala :

- Kebutuhan sosialisasi ulang karena terjadi perubahan pada sistem SIA dan e-Learning.

- Waktu pengembangan aplikasi baru yang lama, terjadi karena :

$\checkmark$ Hak akses yang terbatas untuk mengakses dan menganalisa sistem SIA yang lama.

$\checkmark$ Keamanan atau security yang tinggi pada bahasa pemrograman dan database moodle.

3) SIA + e-Learning dan terdapat aplikasi tambahan SIA + e-Learning dan terdapat aplikasi tambahan maksudnya adalah peneliti tetap menggunakan sistem SIA dan e-Learning yang lama, tetapi peneliti merancang dan mengembangkan aplikasi tambahan atau dapat disebut aplikasi jembatan yang aplikasi tersebut mempunyai fungsi untuk mengintegrasikan sistem SIA dan e-Learning. Gambaran dari alternatif ketiga dapat dilihat pada gambar 4.

Adapun keunggulan dan kendala pada alternatif ketiga ini, keunggulan dan kendala tersebut antara lain :

a) Keunggulan :

- Program integrasi terdapat di antara sistem SIA dan e-Learning jadi akan lebih aman dalam menjalankan sistem.

- User telah familiar terhadap kedua sistem informasi tersebut jadi tidak perlu disosialisasikan kembali.

- Kerja admin akan lebih ringan karena sistem atau aplikasi integrasi SIA dan e-Learning berada tidak di dalam kedua sistem tetapi di antara sistem.

b) Kendala :

Jika terjadi masalah atau kesalahan di aplikasi jembatan, maka akan berakibat pada sistem eLearning karena sistem e-learning menerima integrasi dari sistem SIA dan itu berarti sistem e-learning harus didesign ulang atau diinstal ulang.

Perbandingan antar alternatif, peneliti rangkum pada tabel perbandingan alternatif pada table 1 .

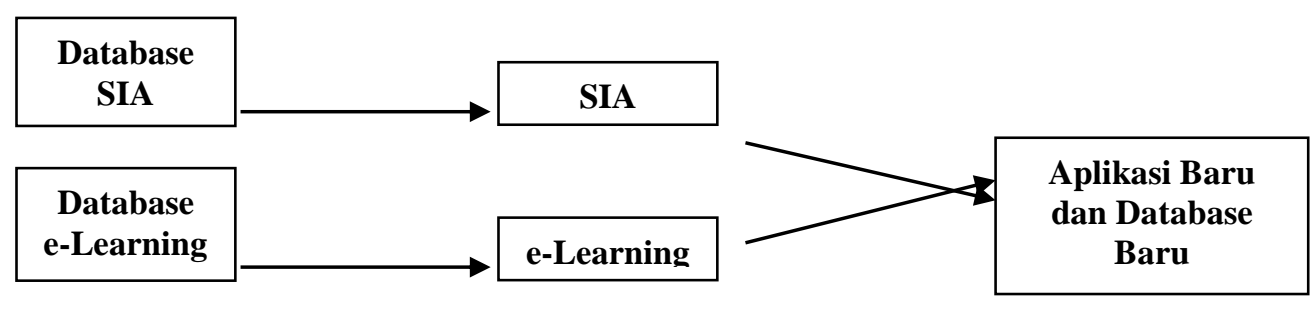

Gambar 2. Desain Sistem Alternatif Pertama

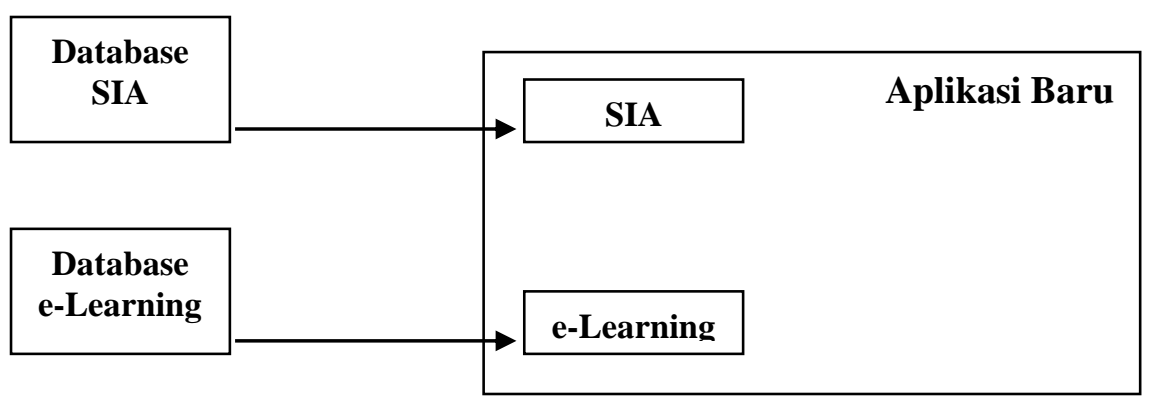

Gambar 3. Desain Sistem Alternatif Kedua 


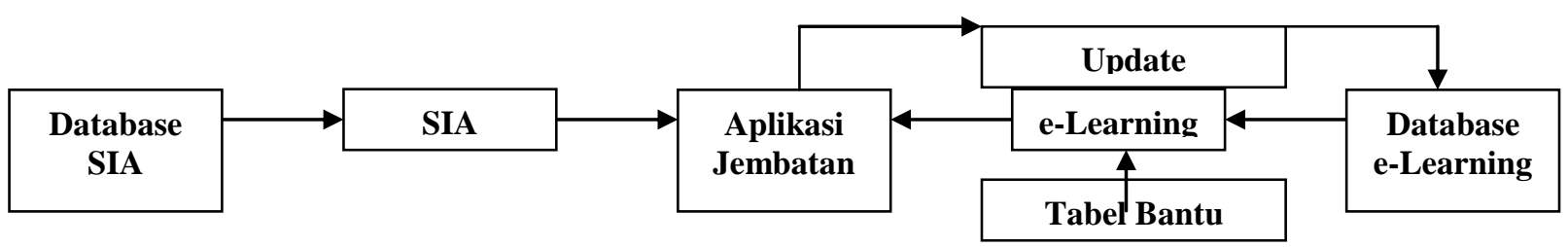

Gambar 4. Desain Sistem Alternatif Ketiga

Tabel 1. Perbandingan antar Alternatif

\begin{tabular}{lccc}
\hline \multicolumn{1}{c}{ Faktor } & Alternatif 1 & Alternatif 2 & Alternatif 3 \\
\hline Waktu Pengembangan & Lama & Lama & Cepat \\
Keamanan Database & Baik & Baik & Baik \\
Keamanan Sistem & Buruk & Buruk & Baik \\
Kebutuhan Sosialisasi & Lama & Lama & Cepat \\
Kebutuhan Migrasi Database & Ya & Tidak & Tidak \\
Kebutuhan Biaya Pengembangan & Besar & Besar & Kecil \\
\hline
\end{tabular}

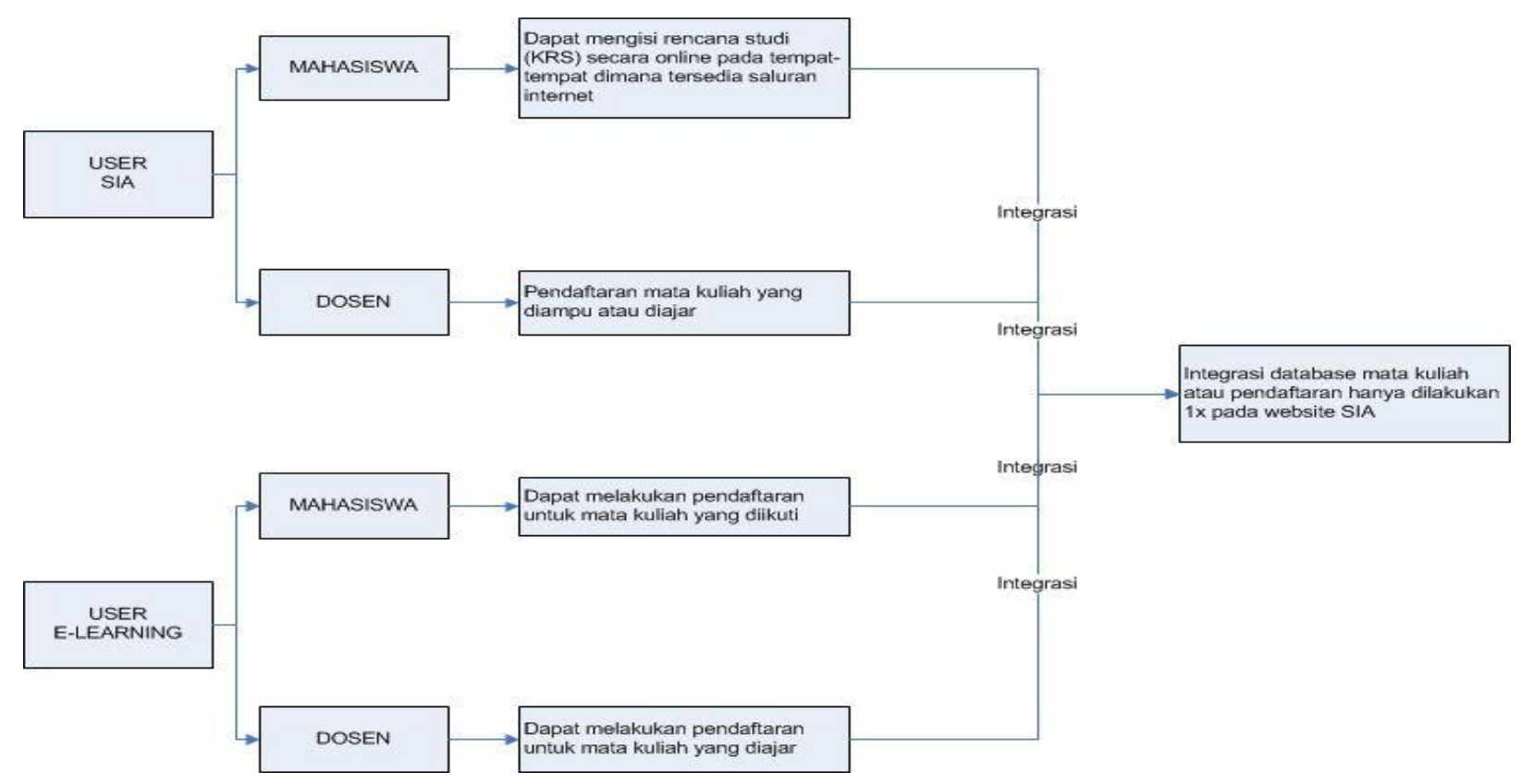

Gambar 5. Struktur Sistem Integrasi

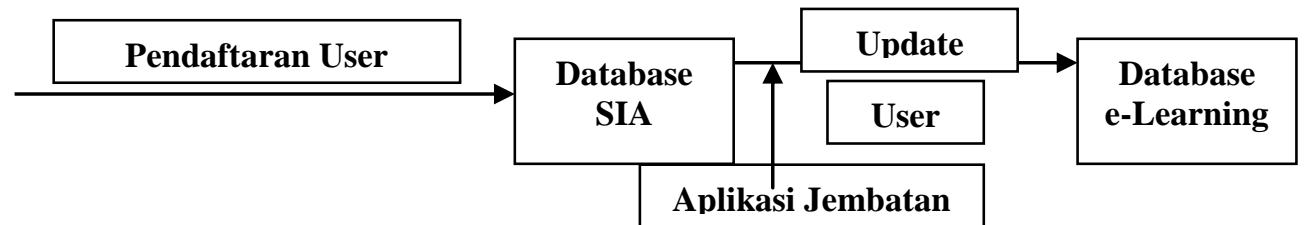

Gambar 6. Struktur Aplikasi Jembatan User 


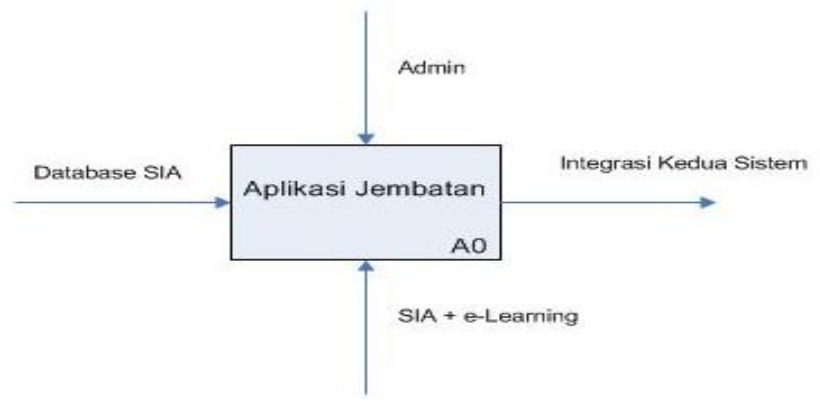

Gambar 7. IDEF0 Struktur Aplikasi Jembatan User

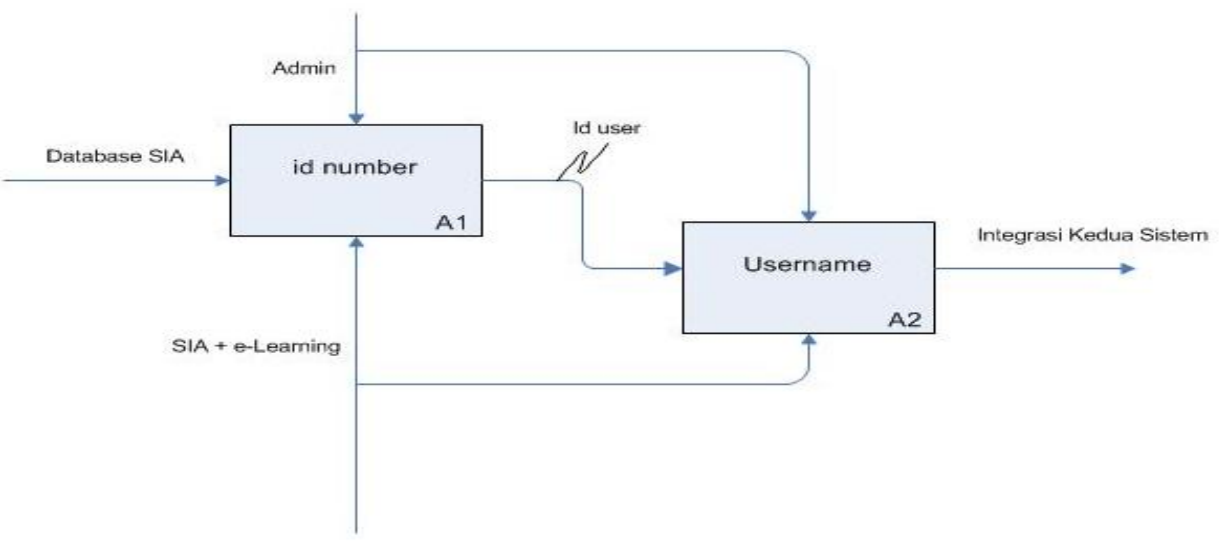

Gambar 8. IDEF0 Level 1 Struktur Aplikasi Jembatan User

Dari tabel perbandingan antar alternatif, terdapat 6 faktor yang mempengaruhi setiap alternatif. Faktorfaktor tersebut didapatkan dari keunggulan dan kendala pada setiap alternatif. Dengan mempertimbangkan perbandingan di atas, maka alternatif yang akan peneliti gunakan adalah alternatif ketiga yaitu SIA + e-Learning dan aplikasi tambahan.

\section{Rancangan Sistem Integrasi}

Rancangan dari sistem integrasi antara Sistem Informasi Akademik (SIA) dengan e-Learning adalah seperti pada gambar 5 .

\section{Integrasi SIA dengan e-Learning} menggunakan Alternatif Ketiga

1) Aplikasi Jembatan User

Aplikasi tambahan atau yang disebut aplikasi jembatan didesain dan dikembangkan dengan bahasa pemrograman php. Aplikasi tersebut akan membaca database SIA khususnya di tabel user dan akan melakukan update pada

2) Aplikasi Jembatan Mata Kuliah

Aplikasi tambahan atau yang disebut aplikasi jembatan didesain dan dikembangkan dengan bahasa pemrograman php dan beberapa tabel bantu yang terletak di database e-learning. Aplikasi tersebut akan membaca database SIA khususnya di tabel krs dan akan melakukan update pada tabel course database e-learning. Selanjutnya admin e-learning akan menjalankan aplikasi jembatan mata kuliah tersebut. Aplikasi jembatan akan melakukan update atau menambahkan data krs yang baru tabel user database e-learning. Pada waktu semester awal mahasiswa baru mendaftar pada SIA, data user (mahasiswa) yang bersangkutan akan tersimpan pada database SIA. Selanjutnya admin pada sistem e-learning akan menjalankan aplikasi jembatan tersebut. Aplikasi jembatan akan melakukan update atau menambahkan data user yang baru ke database e-learning. Jadi user hanya melakukan sekali saja pendaftaran pada SIA.

Untuk IDEF0 struktur aplikasi jembatan user menggunakan input yaitu database SIA. Selanjutnya adminlah yang bertindak mengontrol semua sistem yang berjalan. Mekanisme yang digunakan untuk menyusun sistem tersebut yaitu sistem SIA dan elearning yang akan menghasilkan suatu output yaitu sistem integrasi dari kedua sistem tersebut.

ke database e-learning. Jadi user hanya melakukan sekali saja pendaftaran krs pada SIA.

Untuk IDEF0 struktur aplikasi jembatan mata kuliah menggunakan input yaitu database SIA dan database e-learning. Selanjutnya adminlah yang bertindak mengontrol semua sistem yang berjalan. Mekanisme yang digunakan untuk menyusun sistem tersebut yaitu sistem SIA dan e-learning yang akan menghasilkan suatu output yaitu sistem integrasi dari kedua sistem tersebut. 


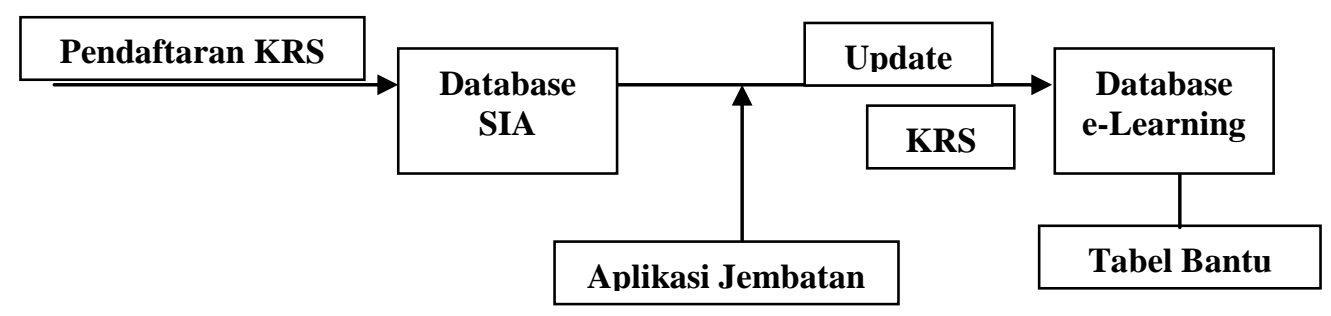

Gambar 9. Struktur Aplikasi Jembatan Mata Kuliah

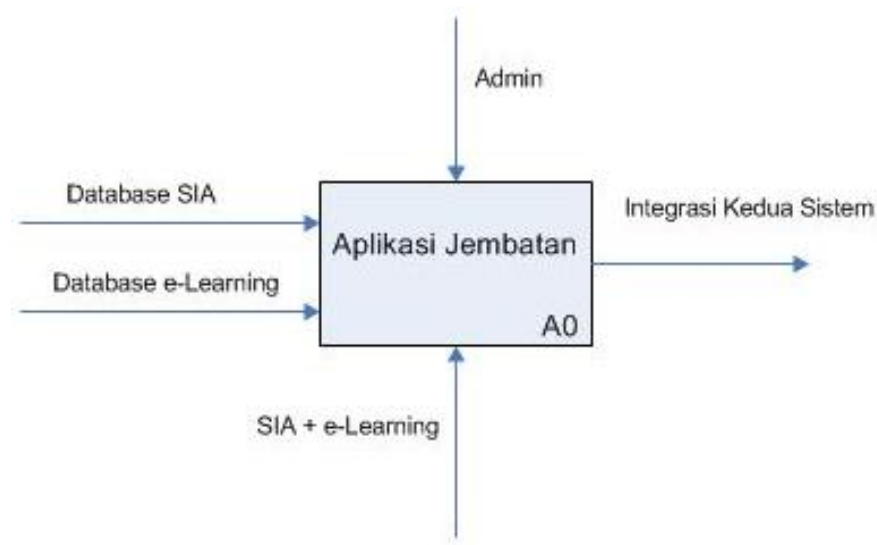

Gambar 10. IDEF0 Struktur Aplikasi Jembatan Mata Kuliah

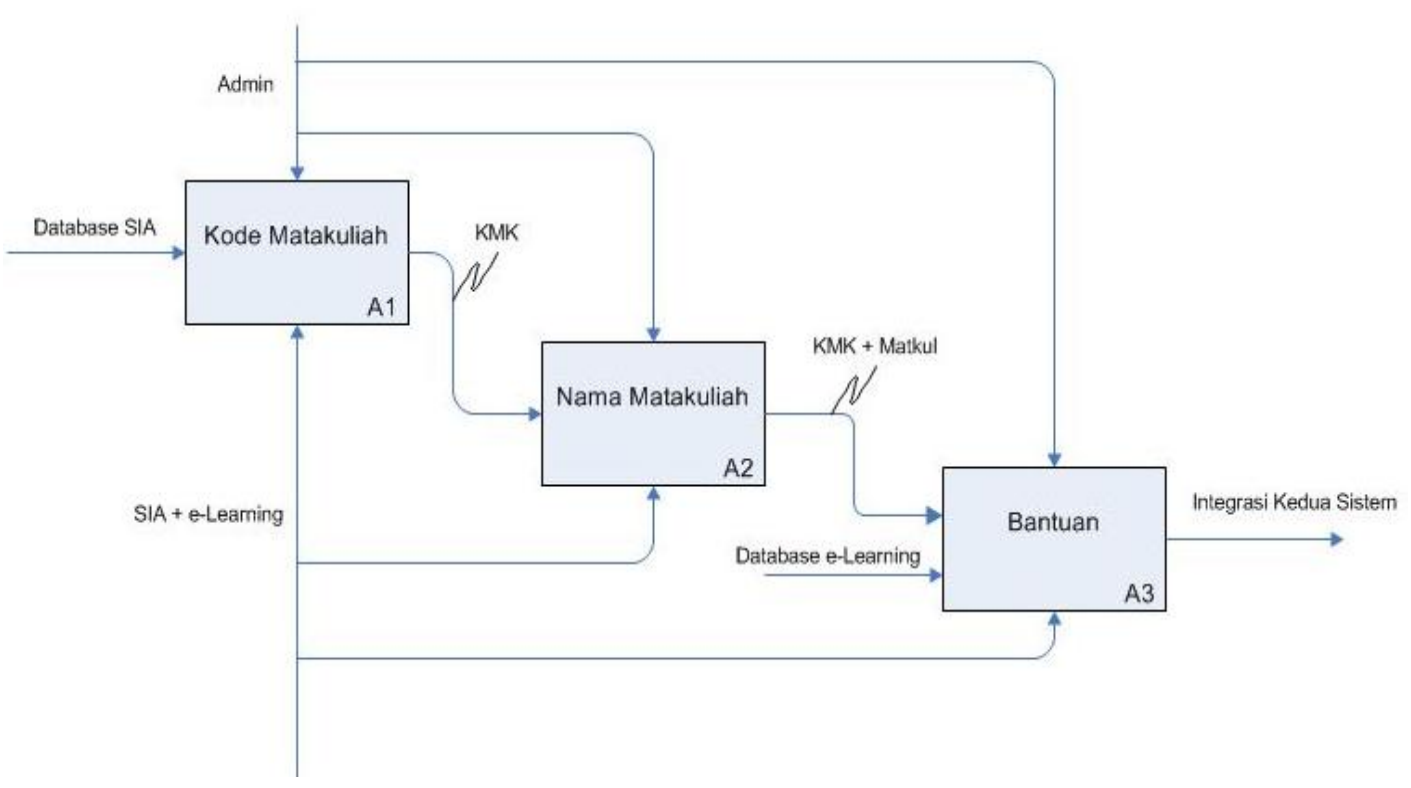

Gambar 11. IDEF0 Level 1 Struktur Aplikasi Jembatan Mata Kuliah 


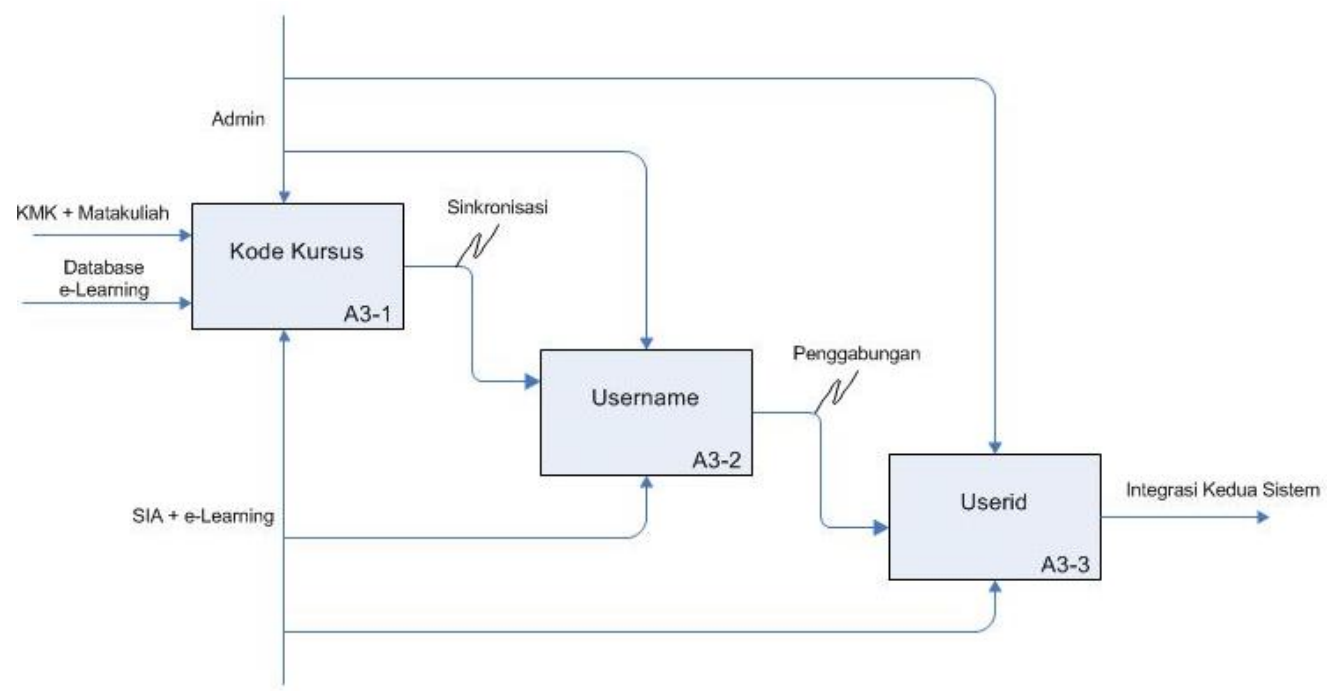

Gambar 12. IDEF0 Level 2 Struktur Aplikasi Jembatan Mata Kuliah

\section{Kesimpulan}

Kesimpulan setelah dilakukannya pengembangan Sistem Integrasi Pembelajaran Berbasis Internet (e-Learning) dengan Sistem Informasi Akademik (SIA) adalah alternatif SIA + elearning dan terdapat aplikasi tambahan merupakan sebuah alternatif yang cocok, karena aplikasi tambahan tersebut berfungsi untuk membantu mengintegrasikan SIA dan e-learning.

\section{Daftar Pustaka}

Cheng, Y., S. H. W. 2010. Applying a 3D Virtual Learning Environment to Facilitate Student's Application Ability - The Case of Marketing. Computers in Human Behavior, 9.

Hartley, E., Darin. 2001. Selling E-Learning. United States of America: Penerbit American Society for Training and Development.

Jin, Q. 2001. Design of a virtual community based interactive learning environment. Information Sciences.

Monahan, T., G. M., Michela Bertolotto 2006. Virtual reality for collaborative e-learning. Computer \& Education, 15.

Neji, M., M. B. A. 2007. Agent-based Collaborative Affective e-Learning Framework. Electronic Journal of e-Learning, 5.
Pan, Z., A. D. C., Hongwei Yang, Jiejie Zhu, Jiaoying Shi. 2005. Virtual Reality and Mixed Reality for Virtual Learning Environments. Computer and Graphics, 9

Redecker, C. 2009. Review of Learning 2.0 Practices: Study on the Impact of Web 2.0 Innovations on Education and Training in Europe. 122.

Rosenberg, Marc Jeffre. 2001. E-Learning Strategies for Delivering Knowledge in the Digital Age, United States of America, McGraw-Hill.

Sharp, H., Rogers, Y., Preece, J. 2007. Interaction Design : beyond human-computer interaction, England, John Wiley \& Sons.

Sudarmawan dan Ariyus, D. 2007. Interaksi Manusia dan Komputer, Yogyakarta, Andi Offset.

Sulianta. 2010. Ergonomi IT, Jakarta, PT Elex Media Komputindo.

Suryadi. 1997. TCP/IP dan Internet sebagai Jaringan Komunikasi Global, Jakarta, Elex Media Komputindo.

Supriyanto, A. 2005. Pengantar Teknologi Informasi, Jakarta, Salemba Infotek.

Tinio, V. L. 2002. ICT in Education.

Uzunboylu, H., H. B., Nadire Cavus. 2010. The Efficient Virtual Learning Environment: A Case Study of Web 2.0 Tools and Windows Live Spaces. Computers and Education, 7.

Wahono, R. S. 2008. Meluruskan Salah Kaprah Tentang e-Learning [Online]. Available: http://romisatriawahono.net. 